\title{
【Original Article】 \\ Study of Inhibitory Effect of Polyphenols from Fragaria ananassa on Fat Accumulation in Rat White Adipocyte
}

\author{
Tetsuro ABE, Saki YOSHIDA, Tetsuro KAWABATA, \\ Fumihide TAKANO, Tomihisa OHTA*
}

Graduate School of Medical, Pharmaceutical and Health Sciences, Kanazawa University

\section{[ABSTRACT]}

On the study of polyphenols from Fragaria ananassa fruit, we reported that some polyphenols showed inhibition of metabolic enzyme, cytochrome P450. Continuous study of health effects of F. ananassa fruit, we isolated a new quercetin glycoside, flagarin, quercetin3-O- $\beta$-glucuronyl- $(2 \rightarrow 1)$ - $\beta$-D-xyloside along with ten known compounds. Those compounds showed inhibitory activity of fat accumulation in rat white adipocyte. Among the isolated compounds, strictinin and the new compound, flagarin showed high inhibitory activity of fat accumulation in rat white adipocyte.

Graphical abstract

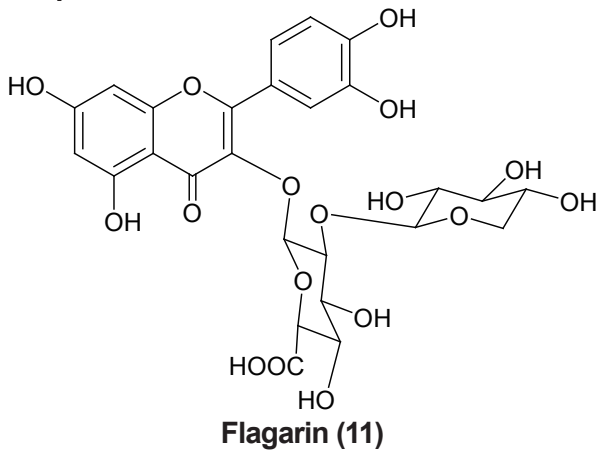

We isolated a new quercetin glycoside, flagarin and ten known compounds from Fragaria ananassa. Those compounds showed fat accumulation inhibition in rat white adipocyte.

【Key words】 Fragaria ananassa, flavonoid glycoside, fat accumulation inhibition, white adipocyte

\author{
【Abbreviations】 \\ UV:Ultra Violet, NMR:Nuclear Magnetic \\ Resonance, CD: Circular Dichroism, \\ HPLC:High Performance Liquid \\ Chromatography, ODS: Octadecylsilane, \\ HRFABMS:High Resolution First Atom \\ Bombardment Mass Spectrometry
}

\section{INTRODUCTION}

Obesity has become one of the social health problems. It increases the risk of chronic diseases such as “diabetes”, "hypertension”, “dyslipidemia”, “coronary artery disease" etc. Recently studies on the effects of dietary polyphenols in the prevention of obesity indicated that polyphenols reduce obesity through several mechanisms. Multiple mechanisms for anti-obesity imply the complexity of the biological functions and also the structural variation of polyphenols. Polyphenols have shown to have variable activity such as antioxidant $^{1)}$, antimicrobial ${ }^{2}$, anti-allergy ${ }^{3)}$, and so on.

In the course of our program to study polyphenols from plant sources, we reported the isolation of some polyphenols from fruits of strawberry, Fragaria ananassa and inhibition of those on the metabolic activity of cytochrome P-4504). Antioxidant activity of strawberry polyphenols such as ellagic acid and some flavonoids ${ }^{5)}$, antibacterial activity ${ }^{6)}$, inhibition of COX enzymes $^{7)}$ and carcinogenic prevention ${ }^{8)}$ have been reported.

We report here the isolation of polyphenols which showed inhibitory activity of fat accumulation in rat white adipocyte, from the edible part of $F$. ananassa.

Along with ten known compounds, we isolated a new quercetin glycoside, flagarin, quercetin-3-O- $\beta$ -

Accepted Date: January 10, 2018

Kakuma, Kanazawa, Ishikawa, 920-1192, Japan Tel: +81 76-234-6888 Fax:+81 76-234-6888

E-mail: ohta@p.kanazawa-u.ac.jp 
glucuronyl-(2 $\rightarrow 1)$ - $\beta$-D-xyloside and determined the structure by spectroscopic analysis and chemical degradation. Among the isolated compounds, strictinin and the new compound, flagarin showed high and concentration dependent inihibitory activity of fat accumulation in rat white adipocyte.

\section{MATERIALS AND METHODS}

\section{General Experimental Procedures}

UV spectra were obtained on a Shimadzu UV-1600 spectrophotometer. Optical rotations were measured on a Horiba SEPA-300 polarimeter. MS spectra were recorded on a JEOL JMS SX-102 mass spectrometer. ${ }^{1} \mathrm{H},{ }^{13} \mathrm{C}$ NMR spectra were measured on a JEOL ECA600 spectrometer with deuterated solvents as internal standards. CD spectra were obtained on a JASCO J-820 spectrometer. Multi spectrophotometer was used Viento XS, Dainippon Sumitomo Pharma. Thermo ELECTRON HEPA CLASS 100 was used for cell incubation. The HPLC system consisted of a Waters 2487 Dual $\lambda$ Absorbance Detector and a Waters 600 Pump. Columns used for separation were Develosil ${ }^{\circledast}$ ODS-HG-5; $20 \mathrm{x}$

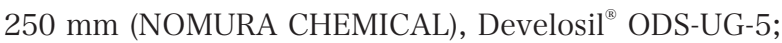
20x250 mm (NOMURA CHEMICAL), Develosil ${ }^{\circledR}$ Packed Column C30-UG-5; 20x250 mm (NOMURA CHEMICAL), Inertsil ${ }^{\circledast} \mathrm{NH} 2 ; 20 \times 250 \mathrm{~mm}$ (GL Sciences). Column chromatography was performed on DIAION ${ }^{\circledR}$ HP20 (Mitsubishi Chemical Corporation), Sephadex LH-20 (Pharmacia), or Wakogel $^{\circledR} 40 \mathrm{C}_{18}$ (Wako). Silica gel 60 $\mathrm{F}_{254}$ (MERCK) and RP-18 $\mathrm{F}_{254 \mathrm{~S}}$ (MERCK) were used for TLC. DPPH, SDS, Mildform ${ }^{\circledR} 20$, and $p$-anisaldehyde were purchased from Wako Pure Chemical Industries. FBS, PC/ST, PBS, Rat white adipocyte, ascorbic acid, biotin, pantothenic acid, insulin, dexamethasone, 3-isobutyl-1-methylxanthine were purchased from TAKARA BIO. MTT reagent was purchased from Nacalai tesque. Trypsin/EDTA was purchased from GIBCO.

\section{Plant Material}

Edible part of Fragaria ananassa "tochi-otome" was provided from Biotherapy Development Research Center, Inc. F. ananassa "tochi-otome" used were cultivated in Tochigi prefecture, Japan.

\section{Extraction and Isolation}

Edible part of $F$. ananassa $(8.00 \mathrm{~kg})$ was extracted with hot water at $90{ }^{\circ} \mathrm{C}$ for $60 \mathrm{~min}$. The crude extract (598 g) was separated on HP-20 chromatography $\left(\mathrm{H}_{2} \mathrm{O}\right.$ $\rightarrow 10 \% \mathrm{EtOH} \rightarrow 50 \% \mathrm{EtOH} \rightarrow \mathrm{EtOH})$ to yield four fractions. 50\% EtOH fraction (30.6 g) having the activity of fat accumulation inhibitory was fractionated with LH-20 chromatography $\left(10,50\right.$ and $100 \% \mathrm{MeOH}$ in $\left.\mathrm{H}_{2} \mathrm{O}\right)$ to get four fractions (Fr. A-D). Fr. B (932 mg) was chromatographed on ODS (15, 30, 40 and $100 \% \mathrm{EtOH}$ in $\mathrm{H}_{2} \mathrm{O}$ ), and the fraction (125 mg) eluted with $15 \%$ EtOH was separated further by ODS chromatography (15, 30, 40 and $100 \% \mathrm{MeOH}$ in $0.1 \% \mathrm{HCOOH})$. The fraction eluted with $30 \% \mathrm{MeOH}$ in $0.1 \% \mathrm{HCOOH}$ was purified by ODS HPLC $(30 \% \mathrm{MeOH}$ in $0.1 \% \mathrm{HCOOH})$ to isolate pelargonidin-3- $O$ - $\beta$-glucoside $(8,7.36 \mathrm{mg})$. Fr. B (3.01 g) was chromatographed on $\operatorname{ODS}(10,15,20,50$ and $100 \%$ EtOH in $\left.\mathrm{H}_{2} \mathrm{O}\right)$ to get Fr. B-1 $(98.0 \mathrm{mg}, 10 \%$ aq EtOH) and Fr. B-2 (317.7 mg, 15-20\% aq EtOH). Fr. B-1 (93.0 mg) was further chromatographed on ODS $\left(\mathrm{H}_{2} \mathrm{O}\right.$; 5, 15, 20, 50 and 100\% $\mathrm{MeOH}$ in $0.05 \% \mathrm{HCOOH})$. Fr. B-1-1 (34.76 mg, 15-25\% $\mathrm{MeOH}$ in $0.05 \% \mathrm{HCOOH}$ ) was purified by ODS HPLC (20\% $\mathrm{MeOH}$ in $0.1 \% \mathrm{HCOOH})$ to isolate 4- $O$ - $\beta$-glucopyranosyl- $p$-coumaric acid $(2,7.36 \mathrm{mg})$ and $(2 R, 3 R)$-2,3-dihydroquercetin-7- $O$ $\beta$-glucoside (7, $1.44 \mathrm{mg})$. Fr. B-1-2 (25.76 mg, 25\% $\mathrm{MeOH}$ in $0.05 \% \mathrm{HCOOH}$ ) was purified by ODS HPLC (20\% $\mathrm{MeOH}$ in $0.1 \% \mathrm{HCOOH}$ ) to isolate brevifolin carboxylic acid (4, $6.45 \mathrm{mg})$. Fr. B-2 (309.4 mg) was fractionated by ODS flash chromatography $\left(\mathrm{H}_{2} \mathrm{O} ; 15,30\right.$, 40 and $100 \% \mathrm{MeOH}$ in $0.05 \% \mathrm{HCOOH})$ to get Fr. B-21 (71.32 mg, 30\% $\mathrm{MeOH}$ in $0.05 \% \mathrm{HCOOH})$, Fr. B-2-2 (54.61 mg, 30\% $\mathrm{MeOH}$ in 0.05\% $\mathrm{HCOOH}$ ), and Fr. B-23 (28.88 $\mathrm{mg}, 30 \% \mathrm{MeOH}$ in $0.05 \% \mathrm{HCOOH}$ ). Fr. B-21 (71.32 mg) was purified by ODS HPLC (17\% $\mathrm{CH}_{3} \mathrm{CN}$ in $0.1 \% \mathrm{HCOOH}$ ) to isolate trans-p-coumaric acid (1, $3.31 \mathrm{mg})$ and (-)-evofolin B (5, $1.86 \mathrm{mg})$. Fr. B-22 (54.61 mg) was purified by ODS HPLC (19\% $\mathrm{CH}_{3} \mathrm{CN}$ in $0.1 \% \mathrm{HCOOH})$ to isolate trans-ferulic acid $(3,2.03$ mg). Fr. B-2-3 (28.88 mg) was purified by ODS HPLC $\left(19 \% \mathrm{CH}_{3} \mathrm{CN}\right.$ in $0.1 \% \mathrm{HCOOH}$ ) to isolate flagarin (quercetin-3- $O$ - $\beta$-glucuronyl-(2 $\rightarrow$ 1)- $\beta$-D-xyloside, 11, 20.82 $\mathrm{mg})$. The part of Fr. C (616.0 mg) was separated by ODS chromatography $\left(10,30,50\right.$ and $100 \% \mathrm{MeOH}$ in $\left.\mathrm{H}_{2} \mathrm{O}\right)$, and the fraction $(310.1 \mathrm{mg}$ ) eluted with $30 \%$ aq $\mathrm{EtOH}$ was further separated by ODS chromatography (10, 15, 20, 25, 30, 35, 40, 50 and $100 \% \mathrm{MeOH}$ in $0.05 \% \mathrm{AcOH})$. The fraction eluted with $20 \% \mathrm{MeOH}$ in $0.05 \% \mathrm{AcOH}$ was purified by ODS HPLC (20\% aq $\left.\mathrm{CH}_{3} \mathrm{CN}\right)$ to isolate quercetin-3- $O$ - $\beta$-glucuronide (10, $9.30 \mathrm{mg})$. Fr. C (203.0 $\mathrm{mg}$ ) was chromatographed on ODS (10, 30, 5 and 100\% $\mathrm{MeOH}$ in $\mathrm{H}_{2} \mathrm{O}$ ). Elution with $50 \%$ aq $\mathrm{MeOH}$ gave the fraction $(7.4 \mathrm{mg})$ which was purified by ODS HPLC (50\% 
$\mathrm{MeOH}$ in $0.1 \% \mathrm{HCOOH}$ ) to isolate kaempferol-3- $O-\beta$ glucoside (9, $2.88 \mathrm{mg})$. Fr. C (2.84 g) was chromatographed on ODS $\left(10,30,50\right.$ and $100 \% \mathrm{MeOH}$ in $\left.\mathrm{H}_{2} \mathrm{O}\right)$. Elution with $30 \%$ aq $\mathrm{MeOH}$ gave the fraction $(1.31 \mathrm{~g})$ which was subjected to flash chromatography on ODS (10, 15, 20, 30 and $100 \% \mathrm{MeOH}$ in $0.05 \% \mathrm{AcOH}$ ). The fraction (545.9 mg) eluted with $20-30 \% \mathrm{MeOH}$ in $0.05 \% \mathrm{AcOH}$ was further fractionated by ODS flash chromatography $(10,15,20,30$ and $100 \% \mathrm{MeOH}$ in $0.05 \% \mathrm{HCOOH})$. Elution with $10 \% \mathrm{MeOH}$ in $0.05 \% \mathrm{AcOH}$ gave the fraction $(22.6 \mathrm{mg})$ which was further purified by ODS HPLC (20\% $\mathrm{MeOH}$ in $0.1 \% \mathrm{HCOOH})$ to isolate strictinin $(6,7.36 \mathrm{mg})$. Flagarin (quercetin-3- $O$ $\beta$-glucuronyl- $(2 \rightarrow 1)$ - $\beta$-D-xyloside, 11$)$. UV $\left(\mathrm{H}_{2} \mathrm{O}\right) \lambda_{\max }$ $(\log \varepsilon) 382$ (4.00), 316 (3.91), 272 (4.23), 198 (8.58); ${ }^{1} \mathrm{H}-\mathrm{NMR}\left(\mathrm{CD}_{3} \mathrm{OD}\right) \delta 3.17$ (H-5,"'a, dd, $\left.J=11.7,12.4 \mathrm{~Hz}\right)$, 3.31 (H-2,”, m), 3.33 (H-3,”, m), 3.45 (H-4”, m), 3.62 (H-4”/5”, m), 3.64 (H-3”, t, $J=8.6$ Hz), 3.74 (H-2”, dd, $J=7.9,8.6 \mathrm{~Hz}$ ), 3.88 (H-5'”'b, dd, $J=11.7,12.7 \mathrm{~Hz}), 4.74$ (H-1"”, d, J=6.5 Hz), 5.57 (H-1", d, $J=7.9 \mathrm{~Hz}), 6.17$ (H6, d, $J=1.7 \mathrm{~Hz}), 6.36$ (H-8, d, $J=1.7 \mathrm{~Hz}), 6.85$ (H-5', d, $J=8.6 \mathrm{~Hz}), 7.57$ (H-6’, dd, $J=2.1,8.6 \mathrm{~Hz}), 7.68$ (H-2', d, $J=2.1 \mathrm{~Hz}) ;{ }^{13} \mathrm{C}-\mathrm{NMR}\left(\mathrm{CD}_{3} \mathrm{OD}\right) \quad \delta \quad 66.5$ (C-5",), 71.0 (C4"’), 73.2 (C-5”), 74.9 (C-2"’), 77.0 (C-3"’), 77.5 (C-3”), 78.0 (C-4”), 82.0 (C-2’), 94.5 (C-8), 99.7 (C-6), 100.9 (C-1”), 105.3 (C-1’”), 105.9 (C-10), 116.1 (C-5'), 117.5 (C-2'), 123.1 (C-1'), 123.3 (C-6'), 135.1 (C-3), 146.0 (C3’), 149.7 (C-4'), 158.4 (C-10), 158.5 (C-2), 163.1 (C-5), 165.7 (C-7), 174.9 (C-6”), 179.5(C-4); HRFABMS $m / z$ : $609.1097[\mathrm{M}-\mathrm{H}]^{-}$(calcd for $\mathrm{C}_{26} \mathrm{H}_{26} \mathrm{O}_{17} 609.1091 \Delta 0.6$ $\mathrm{mmu})$.

\section{Acid hydrolysis of flagarin (11)}

A solution of flagarin $(11)(5 \mathrm{mg})$ in $2 \mathrm{~N} \mathrm{HCl}(2 \mathrm{~mL})$ was heated at $100{ }^{\circ} \mathrm{C}$ for $2 \mathrm{~h}$. The mixture was neutralized by addition of amberlite MB3 in water and evaporated. The crude residue was partitioned with EtOAc- $\mathrm{H}_{2} \mathrm{O}$. The water layer afforded glucuronic acid and arabinose, which were identified with authentic samples by TLC analysis. The water layer was directly analyzed by $\mathrm{HPLC}\left(75 \%\right.$ aq $\mathrm{CH}_{3} \mathrm{CN}$ in $0.1 \% \mathrm{HCOOH}$ $3 \mathrm{~mL} / \mathrm{min}$; UV detection at 210 and $254 \mathrm{~nm}$ ) on ODS$\mathrm{NH}_{2}$ column. The retention time of the peak at 39-46 min coincided with that of xylose. The optical rotation of isolated xylose in this acid hydrolysis was identical with D-(+)-xylose (Tokyo Kasei $[\alpha]_{\mathrm{D}}+20.11^{\circ} c 0.93$ $\left.\mathrm{H}_{2} \mathrm{O}\right)$.

\section{Cell line and culture}

Rat white preadipocytes (White Adipocyte Culture kit, TAKARA BIO INC) in growth medium [DMEM high glucose medium containing fetal Calf Serum $(0.05 \mathrm{~mL} /$ $\mathrm{mL})$, endothelial cell growth supplement $(0.004 \mathrm{~mL} / \mathrm{mL})$, epidermal growth factor $(10 \mathrm{ng} / \mathrm{mL})$, hydrocortisone (1 $\mu \mathrm{g} / \mathrm{mL})$ and heparin $(90 \mu \mathrm{g} / \mathrm{mL})]$ were grown in 24-well culture plates $(10,000$ cells/well $)$ at $37^{\circ} \mathrm{C}$ under $5 \% \mathrm{CO}_{2}$ for $72 \mathrm{~h}$. The cells were differentiated in the differentiation medium [growth medium containing d-biotin (8 $\mu \mathrm{g} / \mathrm{mL})$, 3-isobutyl-1-methylxanthine (44 $\mu \mathrm{g} / \mathrm{mL})$, dexamethasone (400 ng/mL), L-thyroxine (9 ng/mL), ciglitazone $(3 \mu \mathrm{g} / \mathrm{mL})$ and insulin $(0.5 \mu \mathrm{g} / \mathrm{mL})]$ for $48 \mathrm{~h}$. Subsequently, the cells were maintained in growth medium containing $0.5 \mu \mathrm{g} / \mathrm{mL}$ of insulin $(900 \mu \mathrm{L} /$ well).

\section{Inhibition of fat accumulation assay}

Compound 1-11 were dissolved in DMSO following by dilution with the growth medium containing insulin (1\%). Concentration of DMSO was $0.2 \%$. Those sample solutions (each $100 \mu \mathrm{L}$ ) were added to the adipocyte mixture and incubated for $72 \mathrm{~h}$. After removing the culture medium, the cells were washed twice with PBS, fixed with $10 \%$ Mildform ${ }^{\circledast}$ at $4{ }^{\circ} \mathrm{C}$ for $2 \mathrm{~h}$. Removing Mildform was followed by washing the cells with milli$\mathrm{Q}$ water and staining with Oil-red-O (six parts $0.5 \%$ Oilred-O dye in isopropanol and four parts milli-Q water) for $15 \mathrm{~min}$. After rinsing with $100 \mu \mathrm{L}$ of isopropanol/ milli-Q water (3:2) and then with $100 \mu \mathrm{L}$ of milli-Q water, lipid and Oil-red-O were dissolved in $100 \mu \mathrm{L}$ of isopropanol and quantified the lipid accumulation on a microplate spectrophotometer at $540 \mathrm{~nm}$. The percentage of adiposity was calculated as follows: the percentage of adiposity $(\%)=[$ absorbance at $540 \mathrm{~nm}$ (sample)/ absorbance at $540 \mathrm{~nm}$ (control)]x100.

\section{Measurement of cellular toxicity}

In order to examine cellular toxicity, the decline in MTT reduction was measured. MTT was dissolved in PBS at the concentration of $5 \% \mathrm{~W} / \mathrm{V}$, and sterile filtered following to be stored at $4{ }^{\circ} \mathrm{C}$. The cell count was adjusted to $1.0 \times 10^{4}$ cells $/ \mathrm{mL}$. $1 \mathrm{~mL}$ of cell mixture was incubated for $72 \mathrm{~h}$ in 24 -well plates at $37{ }^{\circ} \mathrm{C}$.

The sample solution that was used for cytokine production assay was adjusted to 5, 10 and $50 \mu \mathrm{M}$ respectively using PBS and DMSO medium. LPS solution was also adjusted to $100 \mathrm{ng} / \mathrm{mL}$ using PBS medium. After incubation for $4 \mathrm{~h}$, cells were treated with $20 \mu \mathrm{L}$ of each concentration of samples and $20 \mu \mathrm{L}$ of LPS solution for 24 and 48 h. As a control, cells were treated with $20 \mu \mathrm{L}$ of DMSO and $20 \mu \mathrm{L}$ of LPS solution. After 
the stipulated time, $20 \mu \mathrm{L}$ of MTT solution was added to each well and incubated for $4 \mathrm{~h}$ under $5 \% \mathrm{CO}_{2}$ with light shielding. $100 \mu \mathrm{L}$ of SDS-DMF solution was added to each well and incubated for more $12 \mathrm{~h}$. The color absorbance of each well was recorded at $570 \mathrm{~nm}$ in the medium with a reference serving as blank. The cell viability was calculated as follows: cell viability $(\%)=[a b-$ sorbance at $570 \mathrm{~nm}$ (sample) / absorbance at $570 \mathrm{~nm}$ (control)]xl00.

\section{Statistical Analysis}

All values are presented as Mean \pm SD. The data were analyzed by one-way analysis of varianve (ANOVA). The differences compared with control group were assessed using Dunnett's multiple tests. Statistical significance was considered at $\mathrm{P}<0.05$.

\section{RESULTS}

Edible parts of $F$. ananassa were extracted with hot water at $90{ }^{\circ} \mathrm{C}$ to yield a crude extract. This crude extract was subjected to HP-20 column chromatography. The fraction eluted with $50 \%$ EtOH was separated by column chromatography over LH-20, ODS, and ODS on HPLC to isolate eleven compounds, trans-p-coumaric acid (1) ${ }^{9)}$, 4$O$ - $\beta$-glucopyranosyl- $p$-coumaric acid (2) ${ }^{10)}$, trans-ferulic acid $(3)^{11)}$, brevifolin carboxylic acid (4) ${ }^{12)}$, (-)-evofolin B $(5)^{13)}$, strictinin $(6)^{14)},(2 R, 3 R)$-2,3-dihydroquercetin-7$O$ - $\beta$-glucoside $(7)^{15,16)}$, pelargonidin- 3 - $O$ - $\beta$-glucoside $(8)^{17)}$, kaempferol-3- $O$ - $\beta$-glucoside $(9)$ and quercetin-3$O$ - $\beta$-glucuronide $(10)^{18)}$, and a new flavonoid flagarin (11). The structures of polyphenols isolated in this study are shown in Fig. 1.

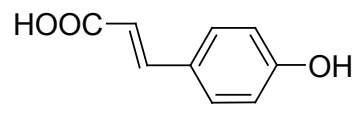

1<smiles>O=C1CC(C(=O)O)c2c1oc(=O)c1cc(O)c(O)c(O)c21</smiles>

4

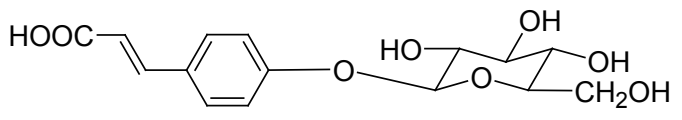

2<smiles>COc1cc(C(=O)C(CO)c2ccc(O)c(OC)c2)ccc1O</smiles>

5

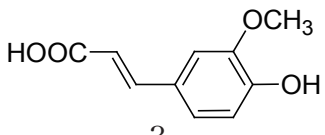

3<smiles>O=C1c2c(O)cc(OOC3OC(CO)C(O)C(O)C3O)cc2OC(c2ccc(O)c(O)c2)C1O</smiles>

7

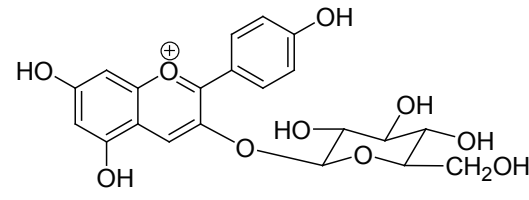

8<smiles>O=C(OCCC(O)C(O)OC(=O)c1cc(O)c(O)c(O)c1-c1c(C(=O)OC2CCCO2)cc(O)c(O)c1O)c1cc(O)c(O)c(O)c1</smiles>

6<smiles>O=C(O)C1C(O)C(O)C(O)C(O)C(O)C1C(=O)O</smiles>

10<smiles></smiles>

9

Fig.1 Chemical structures of 1-11 isolated from strawberry 
The HRFABMS for flagarin (11) showed a mass peak at $\mathrm{m} / \mathrm{z}$ 609.1097 [M-H]', suggesting the molecular formula $\mathrm{C}_{26} \mathrm{H}_{26} \mathrm{O}_{17}$, corresponding fourteen degrees of unsaturation. ${ }^{1} \mathrm{H}$-NMR spectra showed the two sets of aromatic groups. The five aromatic proton signals ( $\delta$ $6.17,6.36,6.85,7.57$, and 7.68 ) were similar to those of compound 9 which has flavon structure. Two anomeric proton signals ( $\delta 4.74,5.57)$ indicated the presence of two saccharides. The presence of $\beta$-glucuronic acid was derived by the ${ }^{1} \mathrm{H}-{ }^{1} \mathrm{H}$ COSY, HMQC, and HMBC spectra (Fig. 2 and 3). The presence of xylose was determined by the comparison of the ${ }^{1} \mathrm{H}-\mathrm{NMR}$ and optical rotation of the hydrolysate of flagarin (11) to those of authentic sample. The structure of flagarin (11) was thus determined by 1-D and 2-D NMR analysis as quercetin-3- $O$ - $\beta$-glucuronyl- $(2 \rightarrow 1)$ - $\beta$-D-xyloside.

The white adipocyte store excess energy as triglycerides in vivo. In the culture test with rat white preadipocyte, fat is accumulated in the culture differentiation process of cells, and changes to white adipocyte causing obesity. Compounds 1-11 were added to those preadipocyte cells and the effect on fat accumulation was assessed by the Oil-red-O Stain method. Most of the isolated compounds showed significant inhibitory effect on fat accumulation in rat white adipocyte (Fig. 4 and 5).

\section{DISCUSSION}

Isolated compounds except for compound 3 and 8 showed inhibitory activity on fat accumulation in rat white adipocyte. In phenylpropanoid group (compound 1-3), the presence of 3-OMe on phenyl is considered

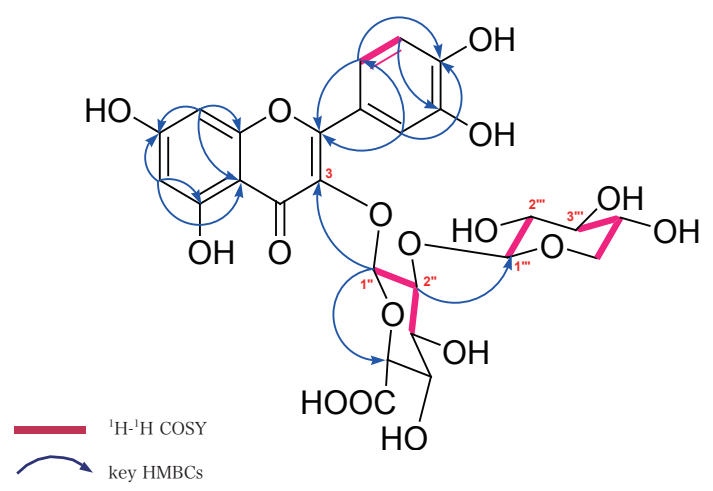

Fig.2 Planar structure of flagarin (11) to be responsible for the fat accumulation inhibitory activity. Among the compounds 2, 4, 6 and 11 showing fat accumulation inhibition, strictinin (6) and the new compound, flagarin (1 1) showed higher inhibitory activity of fat accumulation in rat white adipocyte.

To ensure that fat accumulation inhibitory activity is not due to cellular toxicity of the compounds, we examined the cytotoxicity of compounds 1-11 by MTT method. Experimental results (non-explicit) indicated that the compounds showed least cytotoxicity.

\section{CONCLUSION}

In this study, we isolated eleven polyphenols containing new diglucoside, flagarin (11) from edible part of $F$. ananassa hot water extract. This study indicated that strawberry contains various types of polyphenols which showed the inhibitory activity on fat accumulation in rat white adipocyte.

Whether the fat accumulation inhibitory activity to the white fat cell is related to the obesity prevention action of the human is a future problem. It could be interesting if the strawberry that many people like is relevant to the obesity prevention.

\section{ACKNOWLEDGMENTS}

We wish to thank Biotherapy Research and Development Center Co. Ltd. for generous gift of strawberry fruits.

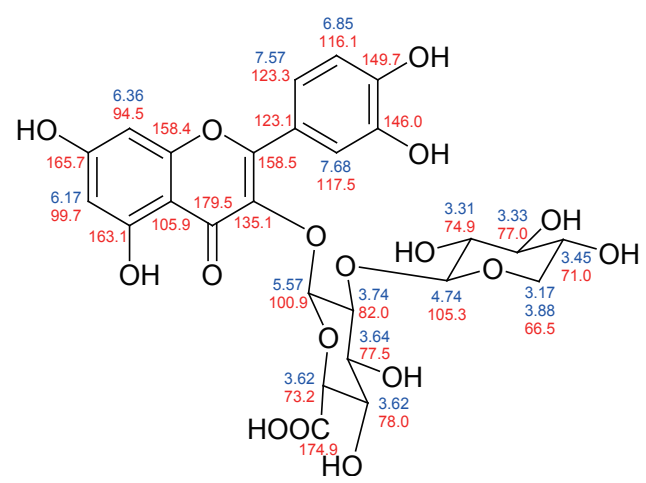

Fig. $3{ }^{1} \mathrm{H}$ and ${ }^{13} \mathrm{C}-\mathrm{NMR}$ spectral data of flagarin (11) in $\mathrm{CD}_{3} \mathrm{OD}$ 


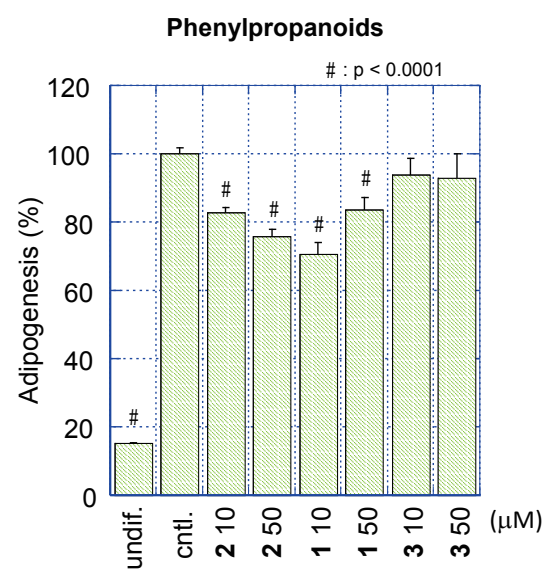

(A) Effect of phenylpropanoids isolated from Fananass

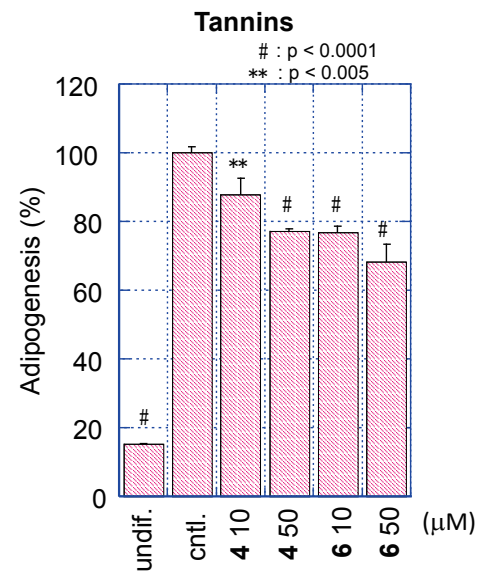

(B) Effect of tannins isolated from $F$. ananassa

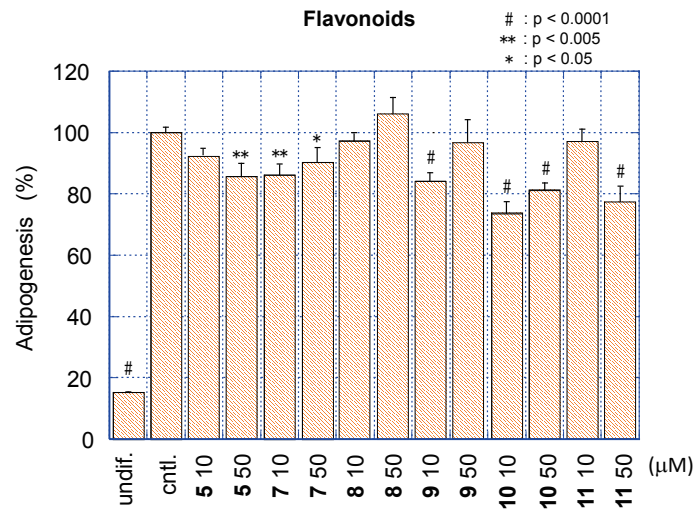

(C)Effect of flavonoids isolated from $F$. ananassa

Fig.4 Effects of polyphenolic compounds on adipogenesis in cultured rat white adipocyte

undif
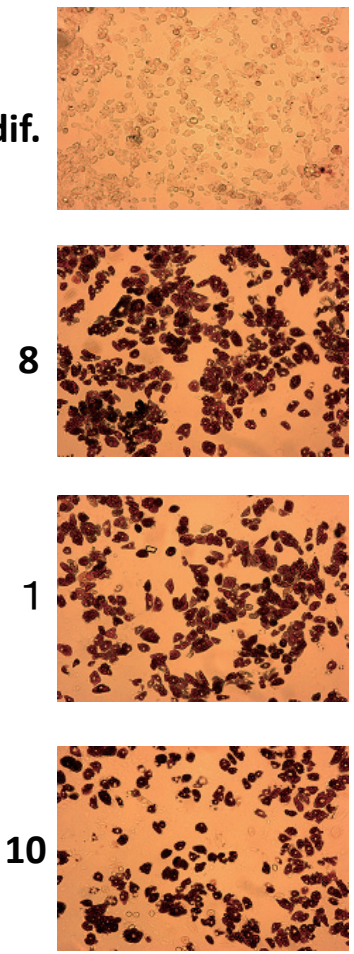

cntl.

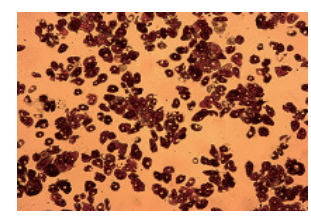

2

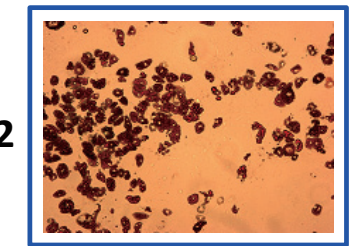

5

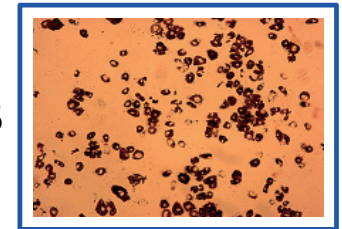

3

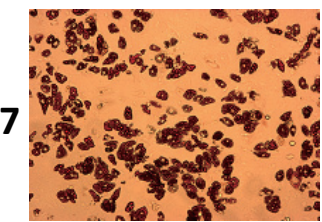

4
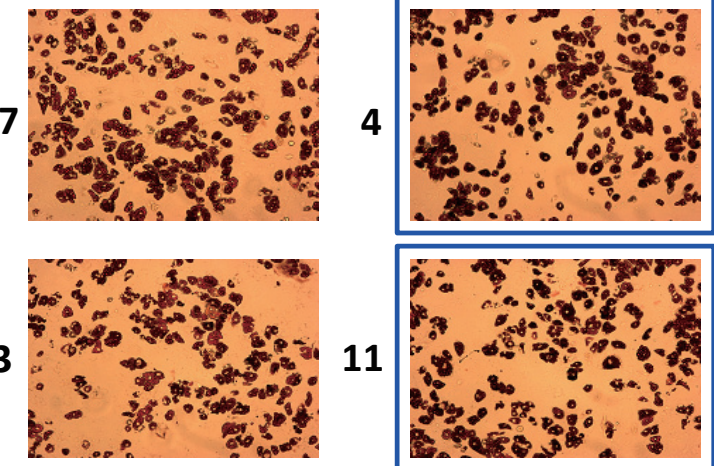

11

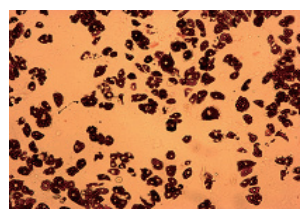

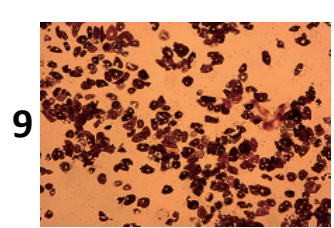

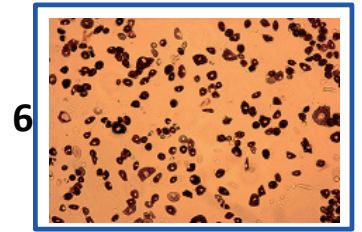

Fig.5 Morphological changes in rat white adipocytes treated with some polyphenolic compounds $(50 \mu \mathrm{M})$ isolated from strawberry. Cells were stained with Oil Red O after cultivation $(\times 200)$. 


\section{REFERENCES}

1) Anesini C, Ferraro GE, Filip R. Total Polyphenol Content and Antioxidant Capacity of Commercially Available Tea (Camellia sinensis) in Argentina. J. Agric. Food Chem. 2008; 56: 9225-9229.

2) Hatano T, Tsugawa M, Kusuda M, et al. Enhancement of antibacterial effects of epigallocatechin gallate, using ascorbic acid. Phytochem. 2008; 69: 3111-3116.

3) Kanda $T$, Akiyama $H$, Yanagida $A$, et al. Inhibitory Effects of Apple Polyphenol on Induced Histamine Release from RBL-2H3 Cells and Rat Mast Cells. Biosci. Biotechnol. Biochem. 1998; 62: 1284-1289.

4) Tsukamoto S, Tomise K, Aburatani M, et al. Isolation of Cytochrome P450 Inhibitors from Strawberry Fruit, Fragaria ananassa. J. Nat. Prod. 2004; 67: 1839-1841.

5) Hannum SM. Potential Impact of Strawberries on Human Health. Crit. Rev. Food Sci. Nutr. 2004; 44: $1-17$.

6) Puupponen-Pimia R, Nohynek L, Hartmonn-Schmidlin $\mathrm{S}$, et al. Berry phenolics selectively inhibit the growth of intestinal pathogens. J. Appl. Microbiol. 2005; 98: 991-1000.

7) Seeram NP, Momin RA, Nair MG, et al. Cyclooxygenase inhibitory and antioxidant cyanidin glycosides in cherries and berries. Phytomed. 2001; 8: 362-369.

8) Mcdougall GJ, Ross HA, Ikeji M, et al. Berry Extracts Exert Different Antiproliferative Effects against Cervical and Colon Cancer Cells Grown in Vitro. J. Agric. Food Chem. 2008; 56: 3016-3023.

9) Kort R, Vonk H, Xu X, et al. Evidence for trans-cis isomerization of the p-coumaric acid chromophore as the photochemical basis of the photocycle of photoactive yellow protein. FEBS Lett. 1996; 382: 7378.
10) Struijs K, Vincken JP, Verhoef R, et al. The flavonoid herbacetin diglucoside as a constituent of the lignan macromolecule from flaxseed hulls. Phytochem. 2007; 68: 1227-1235.

11) Tan J, Bednarek P, Liu J, et al. Universally occurring phenylpropanoid and species-specific indolic metabolites in infected and uninfected Arabidopsis thaliana roots and leaves. Phytochem. 2004; 65: 691699.

12) Hussein SAM, Barakat HH, Merfort I, et al. Tannins from the leaves of Punica granatum. Phytochem. 1997; 45: 819-823.

13) Wu TS, Yeh JH, Wu PL. The heartwood constituents of Tetradium glabrifolium. Phytochem. 1995; 40: 121-124.

14) Yagi K, Goto K, Nanjo F. Identification of a Major Polyphenol and Polyphenolic Composition in Leaves of Camellia irrawadiensis. Chem. Pharm. Bull. 2009; 57: 1284-1288.

15) Pan H, Lundgren LN. Phenolic extractives from root bark of Picea abies. Phytochem. 1995; 39: 1423-1428.

16) Gaffield W. Circular dichroism, optical rotatory dispersion and absolute configuration of flavanones, 3-hydroxyflavanones and their glycosides: Determination of aglycone chirality in flavanone glycosides. Tetrahedron. 1970; 26: 4093-4108.

17) Kuskoski EM, Vega JM, Rios JJ, et al. Characterization of Anthocyanins from the Fruits of Baguaçu (Eugenia umbelliflora Berg). J. Agric. Food Chem. 2003; 51: 5450-5454.

18) Lu Y, Foo LY. The polyphenol constituents of grape pomace. Food Chem. 1999; 65:1-8. 